\title{
ADVOCACY OF PUBLIC INTEREST AS THE IMPERATIVE FOR IMPROVING PUBLIC ADMINISTRATION
}

\author{
Nikovskaya Larissa I. \\ Doctor of Sociology, Chief Researcher of the Institute \\ of Sociology of the Russian Academy of Sciences. \\ Address: B.5, 24/35, Krzhizhanovskaya str., 117218, \\ Moscow, Russian Federation. \\ E-mail: nikovsky@inbox.ru;
}

\section{Yakimets Vladimir $\mathbf{N}$.}

Doctor of Sociology, Chief Researcher of the Institute

for Information Transmission Problems

of the Russian Academy of Sciences.

Address: 19, B.Karetny Pereulok, Moscow,

127994, Russian Federation.

E-mail: iakimets@mail.ru

\begin{abstract}
In the face of the increasing complexity (multidimensionality) of the transforming Russian society and the emerging pluralism of socio-political interests, a growing need in civil society for strengthening the functional capacity of the institute for advocacy and promoting public interest in the public sphere was shown. The modality of this request is enhanced by the crisis conditions of economic development. With the dominance of administrative-bureaucratic approaches to public policy there is a falsification of feedback and a dysfunction of the public sphere in the direction of strengthening the influence of corporate and bureaucratic interests against the public interest, which inevitably leads to increased social tension and protest moods, as well as to a declining level of confidence in state activities and the legitimacy of political power. The subject of this research are successful practices in identifying and advocating the public interest. Among them: the administrative guillotine, associated with the reduction of terms for rendering state and municipal services to entrepreneurs in the Perm region; the preservation of the status and location of the Children's cancer hospital in St. Petersburg; protection of relict lake Harovoye in Kazan; defending the rights of citizens to common house property in Kostroma. The main questions arising while studying the above practices are: who and how articulates the public interest?; what is the role and influence of civil society institutions on regional policy formation?; And, how and in what way are concerned citizens becoming "actors" of public policy, etc? The case study approach was selected as a basic method for this project. The method of content analysis of available publications was applied in all of the selected cases. Descriptions of cases were made on a unified format. In-depth interviews and focus groups were used for clarifying details. It is shown that the development of institutions for public participation, and mechanisms for cross-sectoral social partnership contribute to streamlining interaction between authorities
\end{abstract}


and society. In the conditions of incompleteness of processes for socio-political transformation these approaches also enhance the effectiveness of the social representation of public interests and stimulate the reform of public administration in the direction towards openness and transparency, that help to more adequately take into account the increasing mobility and pluralism of social groups and their socio-cultural preferences. This article summarizes the results of case studies in three Russian regions (Kostroma and Yaroslavl oblasts plus the Republic of Tatarstan). The main conclusion is that in improving the functional capacity of the institute for identification, formation and advocacy of public interests can be reached through enhancing the procedures for citizen engagement in decision making processes, and considering it as an important resource and the basis for improving the quality of modern governance and democracy.

Keywords: public policy; criterion; institutions functional capacity; advocacy of public interests; government, civil society; public participation; state control.

Citation: Nikovskaya, L.I. \& Yakimets, V.N. (2017). Advocacy of Public Interest as the Imperative for Improving Public Administration. Public Administration Issues, Special Issue (electronic edition), pp. 101-116 (in English); doi: 10.17323/1999-5431-2017-0-5-101-116.

\section{Introduction: New Challenges for Public Administration}

The problem of the identification, formation, evaluation, and advocacy of public interests is one of the poorly explored issues of the social development of Russia and simultaneously it is a challenge facing the state structures and civil society. It is obvious that with increasing differentiation in the structure of society, increasing environmental, geopolitical, demographic and other risks, many functions of the modern state are complicated and face the challenges of a more subtle and adequate reflection of the system's diverse interests and the needs of society. Any huge and extensive state apparatus is unable to cope with this problem. There is a growing need for the active engagement of society in the processes of public policy formation (Rhodes, 2003; Hoppe, 2009; Hoffe, 2009). The concept of public policy research draws attention to the nature, process procedure development and implementation of programs for the activities of the authorities at different levels. In general, under public policy (hereinafter $\mathrm{PP}$ ) one can recognize the programs and priorities of the authorities, as well as the mechanisms and technologies of their implementation, designed on the basis of the expectations of different social groups.

Today in Russia, the field of PP is rapidly expandin. Within this field the "agenda" is formed and the monitoring for programs implementation is realized. (Kaufmann, 2010).The structure of public policy is ever complicated. It consists of macroeconomic policy, social policy, communication and information, cultural-symbolic, ethno-national, environmental policy, security policy, etc. The process of implementing public interests and producing public goods becomes a centre pairing differentiated infrastructure of the public sphere. Thus, transformation processes in the public sphere lead to an increased role in the PP formulation and implementation of both state structures and civil associations, which undoubted changes the system of their relations towards greater cooperation.

Two qualitatively different systems of social interest representation - electoralparty and functional - have developed within society (Almond, Powell, 1995; Fabriani, 1990). But the role of these systems within public policy is unequal. The system 
of electoral representation is dominant in Russia. In its turn, the system of functional representation in the process of the socio-political interaction of society and power plays an auxiliary role. However, over recent decades society has become significantly complicated due to the expanding diversity of social interests, of which not all could find its place in the system of party and electoral representation.

The erosion of old social cleavages (especially class) occurred, which again led to a crisis in the system of representative democracy institutions. The system of political administration became substantially complicated and thus demanded more intense socio-political interaction with society (Janda , Kwak, 2011). In other words, all of the above changes required a transition to the direct (not mediated by political parties and elections) format of interaction between the state and public associations, which determined the increasing importance of the system of the functional representation of interests in contemporary societies. All of this raised a very relevant question about the nature of the models of interaction between the state and the so-called "interest groups" (Blondel, 1995; Dzhordan, 1997). The pluralist model considers the political process as the pressure from various interest groups on the authorities and the redistribution, respectively, of power in society. In this case a policy is an authoritative allocation of scarce government resources under pressure from interest groups, which are active factors of the political process, while the state represented by the government as a whole performs the function of a passive response to interest groups. A pluralistic approach does not allow us to explore politics as a system of interconnected relations between the state and society in which the state is not just an agent responding to the call of pressure groups, but an active participant in cooperation (Alekseeva, 2001; Fraenkel, 1991). An analytical model of corporatism in its own way solves the problem of the relationship between public interest and government agencies. In contrast to pluralism, corporatism views the state as a key element in the relations between interest groups and politics (Schmitter, Grote,1997). In accordance with this concept, a limited number of compulsory, non-competing, hierarchically ordered and functionally distinct entities are valid in policy approved or licensed by the state and seek a monopoly on representation in the relevant field. As a rule, corporatist literature includes consideration of the most influential groups - business and labor, and in this sense, it leaves in the shadow many other participants in the political process today which oppose corporatism and build their own relationships with the state, not through a hierarchical relationship. The network approach to policy and governance is developing its research strategy on the basis of a new relationship between the state and society, and between the public and private spheres of social life. The common credo of the policy networks theory is that in contrast to pluralism and corporatism, it is able to "catch" the complexity and fluidity of the contemporary process of political decision-making and policy formulation (Rhodes, 1997). The theory of networks modifies the understanding of power centered policy towards a policy of mutual responsibility and obligations. Thus, the network approach, by emphasizing the increasing significance of the "horizontal lines" in social development, indicates the limitations of hierarchically organized political administration, as opposed to the concept of governance, in which the intensity of relations between the state and society are considered to be bases for an increase in the efficiency of public administration, on the one 
hand, and democracy on the other. The philosophy of this approach was influenced by communitaristic criticism of liberalism and the liberal state (Smorgunov, 2014). In Western thought, this structural shift in the system of criteria for degree of openness and governance quality have led to a transition from the paradigm of "New Public Management" (NPM) to Public Value Management (PVM), when the autonomy of the state is relative and it is limited by the structures of social power. The PVM concept goes beyond the economic approach to public administration and introduces a number of imperatives that describe relations between the state and society in a different way (O'Flynn, 2007). The concept of "co-management" (governance) and good governance (effective management) were first presented to the world community in 1997 in the documents of the United Nations (Report on Human Development 1997). The implementation of the concept of good governance depends on a well-developed and stable institutional and political environment in the state. The institutional environment must provide the ability to accumulate the opinions of numerous political and public actors to facilitate the exchange of opinions, seeking consensus when making political, economic, social and other decisions, with the support of the public.

This stimulated the development of a new concept of governance for the twenty-first century, providing for the wide access of citizens and businesses to governmental information, primarily in the areas of education, health and social security, employment, tax, licensing and the conduct of business, public procurement and government contracting, and international trading operations. The concept also envisaged providing citizens with new channels of communication that allow them to participate in the development of rules that define the relationship between government and citizens, and to exercise permanent control over how these rules are enforced (Manning, Parison, 2003).

\section{Research Methodology}

The subject of our research is successful practices in development together with the advocacy of public interest. In the course of the project we carried out in 2012-2014, we identified and, according to the common format, described about 20 very effective practices for the advocacy of public interests from different regions of the country (Praktiki formirovanija..., 2014)]. Among these: the administrative guillotine, associated with the reduction of the terms of rendering state and municipal services to entrepreneurs in the Perm region; preservation of the status and location of the Children's Cancer Hospital in St. Petersburg; protection of the relict lake Harovoye in Kazan; and advocacy of the rights of citizens to common house property in Kostroma. The main goals and objectives of the analysis are: who articulate public interest, and how?; what is the role and influence of civil society institutions in the formation of regional policy in relation to problem situations - both from concerned citizens and from issues "subject to"public policy, lobbying the interests of the public?; what is the role and possibility of different venues?; and, what tools defend the public interest effectively and how well are citizens and public bodies ble to apply them? The case study approach was chosen as the basic method. One case for detailed study was selected in each region 
(Opportunities and barriers..., 2014). In the Republic of Tatarstan it was the conflict of the protracted confrontation between the residents of the houses around Lake Harovoye in Kazan plus environmentalists against the Tanarstan Ministry of Land Property which has tried to destroy this unique pond by using this territory for new urban development. In Kostroma we studied the case associated with common house property (CHP) at the level of urban and rural municipal formations. Since the mid-1990s. the practice has arisen whereby the CHP of the owners of apartment houses (cellars, lift wells, other premises, etc.) were alienated to third parties. Particular damage to the house and its inhabitants was caused by the selling of technical basements and attics to third parties. Under the Housing Code, the ability of citizens to self-manage their housing could not be realized in the absence of possession of the subject management of the common property of the house. In Yaroslavl we studied the case associated with the engagement of representatives of the NGO community in work regarding the independent evaluation of the quality of social services, delivered by both state and municipal institutions in the region. In each of these case studies, the content analysis of publications method was applied. A description of the case studies was implemented on an unified format. In-depth interviews and focus groups were used as basic instruments. In each region the government officials, staff of NGOs and public associations, mass media representatives, businessmen, academics and civil society activists were interviewed as respondents (from 35 to 40 persons).

\section{Civil Society's Request for Efficient Institutions Enabling Public Interaction with the State}

Russian practices and the format of the publicity of its interaction with civil society are still far from meaningful, or high managerial requirements of Good governance. Nevertheless, the events of administrative reform related to the formation and introduction of the standard of openness to the activities of federal bodies of executive power (Standart..., 2014), implementing a new request for communication openness, including network communities, in new ways highlighted the significance of the study of the phenomenon of the publicity of public administration. The request for well-functioning institutions of public interaction is increasingly focused on by civil society. In our studies, we relied on the analysis of Russian practices in the functional representation of interests, taking into account non-hierarchical social structures based on the priority of public values. In order to compare the efficiency of different institutions of public policy, we have proposed a new criterion - the functional capacity of public policy institutions ${ }^{1}$ (Yakimets, 2014; Nikovskaya, Yakimets, 2015). We calculated the functional ca-

\footnotetext{
1 The Essence of the functional capacity indicator for the PP Institute means the proportion of respondents who put a particular PP Institute in a 10-point scale scores from 6 to 10 points, inclusive, to the total number of respondents evaluating this PP Institute. We recall that in the study of the status of PP in the regions, we interviewed representatives of the three groups of respondents (based on the target sample) - state and municipal servants, representatives of small and medium-sized businesses and NGOs. Each of them were asked to rate on a 10-point scale the effectiveness of PP Institutes or mechanisms and the effectiveness of key players and actors in PP.
} 
pacity of the PP institutions for a number of areas based on data received in surveys in 2012 and 2013 in many regions (Nikovskaya, Yakimets, 2013). Among about 20 PP institutions and mechanisms the following were found to be of low functional capacity: mechanisms of anti-corruption, regional healthcare system, mechanisms of public control over the activity of authorities, and mechanisms for the identification and advocacy of public interests.

Not all PP institutions and mechanisms with low functional capacities can be improved at the federal level. It is the representatives of the regions who will have to decide what needs to be improved first. To ensure the sustainability of social development, an important principle of "horizontal integration" in institutional reform has to be applied. This suggests that the transformation of institutions from the public sphere is not isolated from socio-political actors, but rather it is in close cooperation with the advocacy and promotion of the interests and expectations of the main agents of public fields in the region, who are interested in the effective functioning of the PP institutions.

The principle of publicity has made democratic control over state activities possible. Under the conditions of forming an anti-crisis strategy of development, particularly important is the institution of feedback, which allows the authorities to catch trends in the development of social processes, to make corrections to management decisions, to channel the accumulated social tension, and forces the population to trust in the capacity of representation of their interests, and the right and opportunity to influence the adoption of socially important decisions.

Thus, the problem of studying approaches to the advocacy of public interests was actualized. The need for such a study in Russia is determined by the polarity of the authorities' actions. On the one hand, a package of laws was adopted, which have positive norms and regulations: a program of NGO support, the introduction of the business Ombudsman institute and the spread of the Ombudsman institution to every Russian Federation region, the simplification of the rules of registration for political parties and social movements, partial change of the election legislation, the introduction of governors elections, the redistribution of financial powers between the state and the municipalities, and a system of independent quality assessment of social services. On the other hand, there are actions of a disturbing character: the introduction of the "foreign agent" concept for NGOs, partially financed from abroad (which is dependent on the participation of the NGOs in political activities, however criteria for evaluating such an feature is not clearly described) (Zakonodatel'stvo..., 2014), the tightening regulation on rallies (Ob uzhestochenii..., 2017), a return to the "diffamation norm" in the criminal code (Kleveta i lozhnoe obvinenie, 2012), and a toughening of control over Internet activity (Trojnoj udar..., 2016), etc.

\section{The Status of Institutes Generating and Promoting}

\section{Public Interest in a Regional Dimension}

The problem of identifying and advocating public interest, in respect of which our research has shown a significant imbalance (Nikovskaya, Yakimets, 2014), is closely connected with the most important function of the public sphere, 
in which the interaction of civil society and the state allows for the establishment through public discourse - of public interest. In this process all three components the quality of the development of civil society, the quality of public administration focused on dialogue with society and which considers it as the most important resource of social development and an important factor in the adoption of socially important decisions, and the state of the public sphere itself (transparency and accessibility for the variety of private, particularistic interests) are important.

In summarizing materials of the qualitative research conducted in summerautumn 2013 with the participation of 35-40 experts from three regions (Yaroslavl and Kostroma regions and the Republic of Tatarstan) about the interaction between civil society (represented by social NGOs) and regional authorities in solving problems related to identification and advocacy, we can distinguish some peculiarities of this process.

It is well known that public interest is not a mechanical sum of private and group interests. It is born at the intersection of the joint requests and expectations coming from "below", from society, and decisions on the promises coming from above, from the political and state bodies. These signals occur in the public sphere and, through dialogue, mutual reflection, and active discussion, are much sought after points of agreement, conjugation and solidarity for the formulation of common goals and priorities, forming the basis of public interest.

The ability of civil society to have such an interaction with the government and to understand the public good and interest, some researchers have called it citizenship, or a civil culture of interaction with the state. The main difference with civil associations is that they serve a public purpose, working towards the public good. The role and quality of public sphere development is very important in shaping and advancing the public interest.

The public sphere appears, on the one hand, as a forum for the collective search for citizen's common goals and the means to achieve them, and on the other hand, as a field of practical realizations of these goals in a system of relations and institutions that form the public sector of society and the state. The key features of the interaction between government and society are dealing with shaping public policy and expressing public (social) interest.

The articulation of the main clusters of society's interests in the public space are a means to and a prerequisite of a societal identity which defines the essence and main thrust of the state's public policy. Of concern to the society interests should be discussed, understood, in order to the authorities, and the public itself were able to notice them and appreciate their significance. Then on the agenda of public policy is to identify the issues that really concern the public, as well as to determine their priorities and sequence of their decisions. Practically representatives of all three regions noted that the institutional framework of interaction in the public space in general has developed thus integrative institutions of public interaction were created: there are relevant departments on public relations within the administrations of regions, and public chambers in the regions are functioning. Regional Civil forums have some impact, but... "in order for the channels of feedback between society and government to work effectively, the necessary steps on both sides are needed. The relevant authorities need to communicate ef- 
fectively with their target audience. The government must be ready for dialogue not only "on paper" but in reality." (interview, Yaroslavl). Almost all of the participants of the expert community evaluated the Court of General Jurisdiction as the most cumbersome and inefficient tool in protecting the public interest: "Usually officials dispatch owners of a common house property to the court. But it is a very unproductive problem solving technique, wasteful of time and money with unpredictable results. The court often keep themselves in a pro-government position" (focus group, Kostroma). Regional media plays weak role in shaping public opinion and, consequently, in attracting an audience for reflection and crystallization of the public interest: "the Regional media provide an opportunity for the public to speak or present their point of view only along with the governmental view" (interview, Kostroma).

The Yaroslavl community members clearly indicated that the media are not instruments for forming and conducting real public opinion in the region: "on the one hand, the media are dependent, being financed and therefore they give a unilateral interpretation of the situation. On the other, this is corrected by the Internet. If the information on TV, radio or in newspapers gives filtered news then discussions in social networks and electronic publications can reveal the true picture". In a problem situation, the role of the media is supplemented with online resources, created by the authorities or specifically for the solution of the problem: in Yaroslavl the portal "people's government" is actively working, in Kostroma - through its Internet site (tsgdom.ru.kos), Internet reception rooms, and Internet forums.

But not all interested respondents and proactive citizens involved in the discussion and solution of problematic situations have access to them. It appears that individuals are more inclined to personal channels of communication with the authorities, including the informal ones, which demonstrated the high importance of direct access to those officials who directly take executive and administrative decisions. As a rule, online communities use a signalling function to inform the authorities about the significance of the problem and to mobilize their supporters.

The qualitative surveys in all three regions have shown that particularly in demand nowadays is the role of civic education: "in recent years, the city Administration (since March 2014), under pressure from the public began to hold training seminars (Kostroma city Council Housing managers, etc.)" (focus group, Kostroma). This indicates the perceived importance of a certain competence on the part of civil society in cooperation with the authorities. It turned out that not only the necessary skills of a qualified expert and analytical activities that allow you to systematically see the problem, but it also requires narrow expertise which is aimed at addressing the narrow subject areas of public life. Not all organizations are ready for such systematic and meaningful interaction. The dependent position of public associations and the inability to be engaged in constructive interaction with representatives of the civil service is retained. Thus, representatives of the Kostroma public organizations pointed out the lack of business negotiations skills of business negotiations in the owners of common house properties and their representative social organizations, and the lack of tolerance and professional knowledge in the field of law and regulations. 
Experts of all three regions noted that when solving problems for the advocacy of public interests, the crucial role remains with the state and its bodies. The line on the dominance of state bureaucracy in the public sphere is applied to all structures of society. In relations with civil society organizations and the business community, the authorities give priority to the strengthening of the state. These organizations and associations are seen as "transmission belts" forming a vertical total system of governance controlled from one center. While the Yaroslavl experts noted that the current state of the public administration system does not give an effective framework to generate a long-term strategy of constructive engagement: "Officials are working under contract and they have no incentive to think in a long-term way. NGOs also have limited resources to make long-term plans."

The Kostroma public noted elements of distrust and bureaucratic processing in the activities of the administrative structures, the prevalence of corporate and commercial interests over public ones: "the administration always has the potential to hide something and "to sell" something or other premises of trading." In the Tatarstan case dealing with the protection of the lake of Harovoye, the solution was completely dependent on the decisions of the top executive - the President of Tatarstanm, Minnikhanov R.N.

\section{The Challenge of Constructive Interaction between State Power and Civil Society on the Basis of a Balance of Interests}

Failures and institutional gaps in the interaction of government and civil society as well as a lack of skills for such interaction significantly block the process of identification and advocacy of the public interest, because this process is mutual. Representatives of government and civil society need to learn how to build symmetric bilateral ties, based on the balance of interests. The basis of this process is the art of dialogue, establishing effective communications in order to identify areas of overlapping interests and to create conditions for their approval. These technologies represent a way to achieve the goals in which the subject and object of management exist not as opposite, sometimes antagonistic substances, but as interrelated actors of public relations interested in each other and finding "points for the coordination of interests" as an internal imperative of its existence and success (Communication, 2011). "The authorities need to not be lazy and to listen to public initiatives and avoid the formal approach to the citizens and public organizations. In turn, NGOs should understand that they are designed to help the executive bodies, and get rid of the principle that "they should do everything" (focus group, Yaroslavl). The ability of the public to influence the executive bodies is expanding, activists are increasing their resources (social trust, political resonance, mobilizing a wide range of supporters including politicians). Changes occur not only in the circle of civil society, but also within the structures of government, which has to get involved in public relations with citizens.

However, the public practices of cooperation between the NGO community and authorities related to advocacy and promotion of the public interest are facing administrative resistance. It appear that there are a number of factors behind this. First, the discrepancy between standards in the administrative activities of highly 
formalized management structures, on the one hand, and much more "free" formats which manifests in the social activity of citizens, jn the other hand. The "inconvenience" of interacting with the public often forms the management view that the activities of civil society activists are often a risk for the administrative system. Authorities prefer to abandon the dialogue or settle for the flushing of public initiatives in bureaucratic delays, rather than change their administrative procedures. But what is significant is that where authorities are trying to strictly control the scope of civil initiatives, we have negative consequences - the refusal of residents in different forms of public participation and the recognition of inefficient, low levels of trust and support explodes in confrontation and protest. Successful collaboration occurs where developed civil society institutions are able to persuade the government of the validity and realism of their "agenda", or where the Governor or the mayor is focused on cooperation with civil society institutions.

Overall, our studies of PP in 2010-2014 confirmed that the administrative powers of authority still considerably dominate the public sphere. A complex web of contradictory trends occurring at the interface point between claims for strengthening the regulatory role of the state and increased requests for a "more mature" society having civic participation on an equal footing with it. The young and better-educated people and the residents of large cities and regional cities experience growing need for more active attitude to the social fabric of their lives. Promising areas of civic participation in the eyes of the people today are health, education, active ageing, the adaptation of socially vulnerable groups of the population etc, that is, almost the entire social sphere of society. Many experts have highlighted spheres beyond private interests: environmental protection, human rights, charity. Moreover, it includes forms of such participation which can be described as socio-civic: a key aspect of the modern democratic "agenda" of activists becomes a question of structuring civil society in such a way that it could influence the government on an equal footing to interact with it. The creation of a truly democratic order cannot simply be a result of the "living creativity of the masses from below" and involves various forms of public-state partnerships (Rossijskoe obshhestvo, 2015). Thus, we see how gradually a network model of promotion and representation of interests is formed. But its development depends on a more balanced presence of the hierarchical principle: the state, important as it is, should not be the only actor forming the "agenda," and the adoption of socially important decisions.

\section{A Stronger Request for Transparency in Public Administration and a System for the Representation of Social Interests in the Context of a Network Society}

In summarizing, we can say that the modern democratic state, includes those that the have recently, objectively seeked to build partnerships with civil society, realizing that reliance on civil society is a powerful "root system", giving strength and stability to the political system. However, the search for the optimum in this interaction today is very simple. Socio-cultural changes of the postmodern society 
characterized by "refinement" of the social fabric, increase the fragility of social ties and their "virtualization".

A changing society in the political context of the early twenty-first century generates a request to expand the access of citizens and organizations of civil society to the decision-making process, increasing the transparency of government and its responsibility for its activities to society (Dalton, Scarrow, 2003). A special role is played by the system of representation of social interests in the framework of the increasing publicity of public administration that allows one to maintain a balance in the relationship between state and public associations, protecting it from the threat of "stalling" in a destructive direction. It is known that the development of mechanisms for public participation, institutions, PP, and mechanisms of intersectoral social partnership contribute to the streamlining and efficiency of interacting authorities and society and has a positive impact on improving public administration. That is a significant shift in the environment of civil society when there is a tendency towards the redistribution of the center of gravity of civic engagement from political parties towards non-political public associations, forced to gradually reform the state in the direction of broadening the scope of its openness to society and its needs.

And the role of the "driver" of this transformation of public administration undertook a cross-sector partnership - as a special modern social technology, connecting the search for the balance of interests between business, non-profit community and government on the basis of the identification of "areas of agreement", and compromise in conditions of pluralism and divergent private groups, and administrative interests. Technologies of the cross-sectoral social partnership, in the diversity of its manifestations, are taught to move from the particular or narrow corporate interests in the direction of uncover the underpinnings of public goods and common interests. This requires, in turn, the full development of the public sphere and its important elements as an institution forming and advocating the public interest, which can work only in the presence of feedback channels between the authorities and civil society. In this capacity, many of the public association "third sector" have a special request about the quality of public administration. It should be competent, ensuring the fulfillment of basic functions of government and society, providing essential public good, uncorrupted, transparent, responsible and with constant feedback from society. There should be respect for the rule of law, protection of the rights and freedoms of citizens, including property rights, and the free development of every citizen and group of citizens should be ensured. Such a state, in addition to its other basic functions, can act as a mediator and manager in the resolution of conflicts arising from the diversity of interests. It is important that the public authorities have developed a social mechanism of state control allowing one to control the consideration and use of civil society initiatives. Firstly, this will allow one to avoid the loss of potentially effective public proposals and civic initiatives. "Pearl grain" should not disappear in bureaucratic millstones. It will also enhance the performance of a new social contract through the use of the capacity of civil society organizations. Secondly, it will convince many in civil society that their efforts are not in vain and that they demanded the reform of the system of interaction between authorities and entities. In addition, capa- 
city development for civic engagement self-government support. In this respect, the Federal government is the beginning of an institutional movement to shape public request in January 2014, the concept of openness of the Federal Executive authorities was approved. The concept and its methodological recommendations constitute the so-called standard of openness of the Federal Executive authorities (Standart..., 2014). It is aimed at improving the efficiency and effectiveness of the measures for improving the system of public administration, defined by decrees of the President of Russia from May 7, 2012 and the basic directions of activity of the Russian Government for the period up to 2018. Documents include: the continued implementation of "electronic government"; the organization of broad, multi-channel access to public resources; building a feedback system within civil society; the introduction of a system of internal and external evaluations of the Federal Executive authorities affecting subsequent financial, staffing and other decisions; simplification of the process of public rulemaking, a reflection of socially significant results, the achievement of which directed the work of ministries and departments; communicating the work of the Federal authorities to citizens in an understandable format. In decree No. 601 "On the main directions of improvement of the state administration" of May 7, 2012 Russian President Putin outlined a "road map" for the development of public-state governance (Yakimets, 2015) by declaring innovations and the timing of their implementation.

The challenge of "publicity" in a networked society claimed a new type of civic competence - professionalism, with the ability to negotiate "on the merits", without the intervention of external mediators. The process of preparation and decision-making became particularly sensitive to the requirements of the procedure. There has been a noticeable increase in the number of participants. An attempt to establish a connection with the real interests and sentiments of various interest groups with public priorities began to be viewed in the decision making process. But this twist is very fragile and is still quite controversial. By opening new opportunities for civil society, it also creates new problems. First, new requirements are imposed on participants. In order to successfully operate in the mode of consultations, civil society representatives need to increase their competence in matters of public policy and protect their socio-political autonomy and the right to equal participation in making socially important decisions. In the field of competence, the administrative authorities possess a "natural monopoly". This dominates not only the executive and administrative power and political influence, but also as the monopoly of professional competence. Experience related to the contradictory process in the formation of independent systems for the quality assessment of social services in the regions confirms this. It is clear that the request for quality of social services to the population, protected from corruption, is an expression of the public interest, but it needs systematic implementation: legal, methodological, expert, organizational, etc., and representatives of civil society organizations here are put in a difficult situation. Secondly, the consultation runs the risk of increasing bureaucratic corporatism.

A traditional bureaucracy is not ready for equal dialogue with partners who are trying to enter the circle of public consultation. The formation of the state regional policy is continued to be as a part of bureaucracy prerogatives. The par- 
ticipation of citizens was perceived as an attack on the sovereign territory of the Executive. Many community organizations and structures, not having reliable channels for the representation of interests and political connections, are outside the scope of "paradigms of harmonization", which has more functions in the spirit of bureaucratic-elitist corporatism. New challenges of social development, generated by the increasing complexity of the socio-political transformation, are creating an increased demand for a more effective functioning of the public institutes of public administration.

In the current environment, we observe a contradictory situation for the development of the PP institutions, and in particular, the institute of advocacy and promotion of the public interest. The findings of our study have problematized the overall context of this situation - how to make an effective system of the social representation of public interests under the conditions of the incompleteness of the transformation process, how to adapt the administrative machinery of the state to significant shifts in civil society to be able to more adequately take into account the increasing mobility and pluralism of social groups and their socio-cultural and national preferences. But on the other hand, civil society itself wondering how it is ready for systematic and painstaking work in cooperation with state bodies, whether the necessary level of civil competence to provide independent expert assessment and public control over the activities of authorities. These properties make civil society an independent and strong player in collaboration with the state bureaucracy, which allows to advocate the public interest and to ensure the sustainable development of society.

\section{REFERENCES}

1. Alekseeva, T.A. (2001). Plyuralizm: istoki i kontseptsii. In: Politicheskii Politicheskiy plyuralizm v sovremennoi Rossii. Pljuralizm: istoki i koncepcii kontseptsii [Pluralism: the Origins and Concepts. In: Political Pluralism in Modern Russia]. Moscow, pp. 40-46.

2. Almond, G.A. \& Powell, G.B. (1995). Comparative Politics Today: A World View. N.Y.

3. Blondel, J. (1995). Comparative Government: An Introduction. Cambridge. 
4. Dalton, R.J. \& Scarrow, S.E. (2003). Democracy Transformed? Expanding Political Opportunities in Advanced Industrial Democracies. Paper 03-04. Center for the Study of Democracy, University of California, Irvine. Available at: http://repositories.cdlib. org/csd/03-04, pp. 1-19. (accessed: 25 April, 2016).

5. Danilova, N.Y., Gurova, O.Y. \& Zhidkova, N.G. (eds.) (2008). Publichnaya politika: ot teorii $k$ praktike [The Public Policy: from Theory to Practice]. Saint. Petersburg.: Aleteiya.

6. Dzhordan, G. (1997). Gruppy davlenija, partii i obshhestvennye dvizhenija: est' li potrebnost' v novykh razgranichenijakh? [Pressure groups, Parties and Social movementsMovements: is there a Need for new Distinctions?]. MEiMO, no 1, pp. 83-98.

7. Fabriani, S. (1990). Politika i interesy. In: Politologiya vchera i segodnya. Vypusk 2 [Policy and interests. In: The political science of yesterday and today. Issue 2]. Moscow, p. 124.

8. Fel'dman, P.JaYa. (2014). Politicheskii kraudsorsing kak institut elektronnoi demokratii: problemy stanovleniya i razvitiya [Political Crowdsourcing as an Institution Ofas an Institution of E-Democracy: Problems of Formation and Development]. Vlast', no 6, pp. 21-26.

9. Fraenkel, E. (1991). Deutschland und die westlichen Demokratien [Germany and the Western Democracies]. Frankfurt/M.

10. GARANT.RU (2014). Zakonodatel'stvo o nekommercheskikh organizatsiyakh, vypolnyayushchikh funktsii inostrannogo agenta: sootvetstvuet Konstitutsii ili net [Legislation on non-commercial organizations performing functions of a foreign agent: conform to the Constitution or not]. GARANT.RU: Legal information portal. Available at: http://www.garant.ru/article/529521/ (accessed: 4 July, 2017).

11. Geektimes, (2017). Troinoi udar dlya Runeta: identifikatsiya pol'zovatelei, kontrol' saitov $i$ elektronnye platezhi [Triple blow for Runet: identify users, control of sites and e-payments]. Available at: https://geektimes.ru/post/209312/ (accessed: 4 July, 2017).

12. Gorshkov, M.K. \& Petukhov, V.V. (eds.) (2015). Rossiiskoe obshchestvo i vyzovy vremeni. Kniga pervaya [Russian Society and Temporal Challenges. $1^{\text {st }}$ Book One]. Moscow: Publishing House "All the World", pp. 318-319.

13. Hoffe, O. (2009). Ist die Demokratie zukunft fahig? Uber modern Politik. [Whether a viable Democracy in the Future? About Modern Politics]. Munchen: Verlag C.H. Beck oHG.

14. Hoppe, R. (2009). Scientific Advice and Public Policy: Expert Advisers' And Policymakers' Discourses Onon Boundary Work. Poiesis \& Praxis, no 6 (3-4), p. 235-263.

15. Janda, K. \& Kwak, J.-Y. (2011). Party Systems and Country Governance. London, Paradigm Publishers. pp. 3-17.

16. Kaufmann, D. (2010). Governance Matters 2010: Worldwide Governance Indicators Highlight Governance Successes, Reversals, and Failures. Washigton, DC: The Brookings Institution, Available at: http://www.brookings.edu/opinions/2010/0924_wgi_ kaufmann.aspx (accessed: 24 September, 2010). 
17. Mjenning, N. \& Parison, N. (2003). Reforma gosudarstvennogo upravleniya: mezhdunarodnyi opyt [Public Administration Reform: International Experience]. Moscow: Ves' Mir.

18. Moskovskoe byuro po pravam cheloveka, (2017). Ob uzhestochenii zakona o mitingakh [About the Tightening of the Law on Rallies]. Moskovskoe byuro po pravam cheloveka. Available at: http://pravorf.org/index.php/news/2379-ob-uzhestocheniizakona-o-mitingakh (accessed: 4 July, 2017).

19. Nikovskaya, L.I. \& Yakimets, V.N. (2013). Otsenka deistvennosti institutov publichnoi politiki v Rossii [Evaluation of the Impact of Public Policy Institutions in Russia]. Politicheskie issledovaniya. POLIS, no 5, pp. 77-86.

20. Nikovskaya, L.I. \& Yakimets, V.N. (2014). Povyshenie kul'tury publichnoi politiki vyzov dlya demokraticheskogo razvitiya Rossii [On Improving Public Policy Culture as Challenge for Democratic Development of Russia]. Vlast', no 9, pp. 5-10.

21. Nikovskaya, L.I. \& Yakimets, V.N. (2015). O sostoyatel'nosti institutov publichnoi politiki [On Consistency of Public Policy Institutions]. Vlast', no 6, pp. 6-22.

22. O’Flynn, J. (2007). From New Public Management to Public Value: Paradigmatic Change and Managerial Implications. The Australian Journal of Public Administration, vol. 66, no 3, p. 361.

23. Open government (2014). Standart otkrytosti Federal'nykh organov ispolnitel'noi vlasti [Standard of Openness for Federal Ministries]. Available at: http://open.gov. ru/events/5508409/ (accessed: 4 July, 2017).

24. Osborne, S.P. (2010). The new public Governance? Emerging Perspectives on the Theory and Practice of Public Governance. London and New York: Routledge.

25. RAGS, (2011). Svyazi s obshchestvennost'yu v politike i gosudarstvennom upravlenii [Relations with Public in Policy and State Management]. Moscow: Publishing House RAGS, p. 112.

26. Rhodes, R.A.W. (1997). Understanding Governance: Policy Networks, Governance, Reflexivity and Accountability. Buckingham, Philadelphia: Open University Press.

27. Rhodes, R.A.W. (2003). The New Governance without Government. In: Understanding Governance Policy Networks, Governance, Reflexivity and Accountability. Maidenhead: Open University Press, pp. 46-53.

28. Schmitter, Ph. \& Grote, J. (1997). Corporatist Sisyphus: Past, Present and Future. San Domenico.

29. Smorgunov, L.V. (2014). Gosudarstvennaya upravlyaemost' i spornaya politika. In: Vzaimodeistvie vlasti i grazhdanskogo obshchestva $v$ kontekste transformatsii rossiiskogo obshchestva: ot konfrontatsii k partnerstvu [Interaction of Administration and Civil Society within Framework of Russian Society Transformation: From Confrontation to Partnership]. Kursk: South - Western State Univ., pp. 225-226.

30. Tsentr sudebnoi zashchity, (2012). Kleveta i lozhnoe obvinenie [Slander and False Accusation]. Tsentr sudebnoi zashchity Pervaya kollegiya. Available at: http://opravdaem. ru/crimes-against-honor/kleveta-i-lozhnoe-obvinenie/ (accessed: 4 July, 2017). 
31. UNDP (1997). Human development report. New-York: Oxford University Press Publishing. Available at: http://hdr.undp.org/sites/default/files/reports/258/hdr_1997_ en_complete_nostats.pdf (accessed 25 April, 2016).

32. Yakimets, V.N. (2014). Ob otsenke sostoyatel'nosti institutov publichnoi politiki $\mathrm{v}$ regionakh Rossii. [Evaluating consistency of Public Policy Institutions in Russian Regions]. In: Materialy II Vserossiiskogo nauchno-obrazovatel'nogo foruma s mezhdunarodnym uchastiem "Politologiya - XXI vek: politicheskie tsennosti i politicheskie strategii". [Proceedings of the $2^{\text {nd }}$ All-Russian Scientific and Educational Forum with International Participation "Politology - XXI Century: Political Values and Political Strategies"]. Moscow. Available at: http://polit.msu.ru/pub/XXI-2/3/38.pdf (accessed: 13 July, 2017).

33. Yakimets, V.N. (2015). Obshchestvenno-gosudarstvennoe upravlenie [Public Policy and Public Administration]. In: Gosudarstvennoe upravlenie: Rossiyskaya Federatsiya $v$ sovremennom mire. XXII Mezhdunarodnaya konferentsiya fakul'teta gosudarstvennogo upravleniya MGU im. M.V. Lomonosova, 29-31 maya 2014 g. [Public Administration: Russian Federation in Contemporary World. XII International Conference of Public Administration Department of the Moscow State Univ. 29-31 May 2014]. Moscow: "Infra-M". pp. 214-219. Available at: http://znanium.com/catalog. php?bookinfo=514674 (accessed: 25 April, 2016).

34. Yakimets, V.N., Nikovskaya, L.I. \& Sokolov, S.V. (eds.) (2014). Vozmozhnosti i bar'ery uluchsheniya regional'nykh mekhanizmov formirovaniya $i$ otstaivaniya obshchestvennykh interesov [Opportunities and Barriers to Improving Regional Mechanisms for the Formation and Upholding of Public Interest]. Yaroslavl': IP Durynin.

35. Yakimets, V.N., Nikovskaya, L.I. \& Sokolov, S.V. (eds.) (2014a). Praktiki formirovaniya $i$ otstaivaniya obshchestvennykh interesov: opyt regionov Rossii [The practice of Developing and Defending the Public Interest: the Experience of Russian Regions]. Yaroslavl': IP Durynin V.V. 